\title{
Survival and developmental characteristics of the predatory bug Orius similis (Hemiptera: Anthocoridae) fed on Tetranychus cinnabarinus (Acari: Tetranychidae) at three constant temperatures
}

\author{
Shi-Chang ZHANG*, Fen ZHU, XiA-Lin ZHENG, Chao-Liang LEI and Xing-Miao ZHOU** \\ Hubei Insect Resources Utilization and Sustainable Pest Management Key Laboratory, College of Plant Science and Technology, \\ Huazhong Agricultural University, Wuhan, 430070, China
}

Key words. Hemiptera, Anthocoridae, Orius similis, Acari, Tetranychidae, Tetranychus cinnabarinus, biological control, development characteristics, functional response

\begin{abstract}
Developmental characteristics of the predatory bug Orius similis fed on Tetranychus cinnabarinus were investigated at three constant temperatures $\left(25,28\right.$, and $\left.31{ }^{\circ} \mathrm{C}\right)$ under laboratory conditions $(75 \pm 5 \%$ relative humidity and a $14 \mathrm{~L}: 10 \mathrm{D}$ photoperiod). The survival of nymphs was highest at $28^{\circ} \mathrm{C}(75.57 \%)$ and at this temperature female adults $O$. similis had the longest oviposition period $(21.1 \mathrm{~d})$, the greatest fecundity $(40.3 \mathrm{eggs})$ and the highest potential intrinsic rate of increase $\left(\mathrm{r}_{\mathrm{m}}: 0.108 \mathrm{~d}^{-1}\right)$. These results suggest that $O$. similis can maintain greater population densities at $28^{\circ} \mathrm{C}$ than at the other temperatures tested. In addition, the functional response indicates that the attack rate of $O$. similis $(1.04)$ and the maximum prey capacity $(30.7$ spider mites per bug in $24 \mathrm{~h}$ ) are greatest at $28^{\circ} \mathrm{C}$. The results of this study provide useful information on the biology and time when to release $O$. similis in order to reduce the abundance of $T$. cinnabarinus in cotton fields.
\end{abstract}

\section{INTRODUCTION}

The carmine spider mite Tetranychus cinnabarinus (Boisduval) (Acari: Tetranychidae) is one of the most economically important pests of vegetable crops and ornamental plants around the world (Capinera, 2001). Nymphs and adults primarily cause damage by feeding on the underside of leaves. The upper surfaces of leaves often become reddish and discoulored before senescing prematurely. When examined closely, fine strands of silk are usually visible near the veins and midribs close to areas of discolouration (Sengonca, 1982; Mo \& Liu, 2006). In the western region of America, more than 10 generations of $T$. cinnabarinus can develop on a cotton plant in a season (Falcon \& Smith, 1973) and it is the most serious crop mite pest in China (Feng et al., 2011). Its high reproductive capability, short life cycle and high rate of inbreeding result in quick developing resistance to pesticides, including miticides (He et al., 2005). Since the $1980 \mathrm{~s}$, the level of resistance of T. cinnabarinus to pesticide has increased rapidly in China, sometimes even by as much as a 152 fold increase (Guo \& Zhao, 1999). As a result, the efficacy of many pesticides has declined and the cost of crop production and level of pesticide residues have increased. Biological control of $T$. cinnabarinus is an alternative strategy, which has no toxic side effects compared with chemical control (He et al., 2005).

Anthocorid bugs are well-known biological control agents because they are polyphagous and eat a wide range of pest species. Previous literature is mainly on the use of Orius spp. for the biocontrol of thrips (Dogramaci et al.,
2011), aphids (Bulter \& O’Neil, 2006; Zhou et al., 2006), and young larvae or eggs of some lepidopterous insects (Bonte \& De Clercq, 2011). However, little attention has so far been devoted to using Orius spp. for controlling spider mites (Xu et al., 2006; Fathi, 2009).

Orius similis Zheng (1982), occurs in southern China where it is an important predator in agroecosystems. Its adults and nymphs eat a variety of pests, such as aphids (Zhou et al., 2006), flower thrips, and young larvae and eggs of some lepidopterous insects and spider mites (Zhou \& Lei, 2002) on more than 20 vegetable crops. Moreover, O. similis can prey on pests from March to October when the temperature is $20^{\circ} \mathrm{C}$ to $37^{\circ} \mathrm{C}$ and produce four to eight generations per year in four provinces (Henan, Hubei, Hunan, and Guangxi province) of China (Zhou \& Lei, 2002). One generation of $O$. similis takes approximately 30 days and one mated female adult can produce 20 to 100 offspring over a period of 10 to 30 days. Moreover, the number of $O$. similis can reach $260 / 100$ cotton flowers in the field during summer and one bug can in the absence of other prey kill 500 carmine spider mites during its life time (Lei, 1997). The spider mite is one of the three preferred prey items (flower thrips, aphids and spider mites) of $O$. similis according to Lei (1997). However, although the life history characteristics of $O$. similis fed on $T$. cinnabarinus are unknown there are some studies of these characteristics when it is fed on aphids (Zhou et al., 2006; Ahmadi et al., 2007).

The mass rearing of Orius for release into the field or greenhouses for the biological control of pests is feasible

\footnotetext{
* Current address: Department of Biological Sciences, National University of Singapore, 117543, Singapore

** Corresponding author; e-mail: xingmiaozhou@yahoo.com
} 
and could result in the reduction in the use of pesticides (Bonte \& De Clercq, 2011). However, before releasing these bugs it is important to determine the temperature at which this bug is most efficient at controlling pests and the best time to release them in the field. In the present study, the development and predatory activity of the anthocorid bug, $O$. similis, against the carmine spider mite, T. cinnabarinus, at three temperatures was determined. The temperatures were close to the average monthly temperatures recorded in the Yangtze River area from May to September. The aim of this study was to provide information on the potential use of $O$. similis in integrated pest management (IPM) programs.

\section{MATERIAL AND METHDOS}

\section{Insect and mite cultures}

Anthocorid bugs of the species $O$. similis were collected from cotton flowers in the grounds of Huazhong Agricultural University, Wuhan City $\left(30.5^{\circ} \mathrm{N}\right.$ latitude and $114.3^{\circ} \mathrm{E}$ longitude), Hubei Province, P.R. China. Stock cultures were maintained in an insectary according to the method described by Zhou et al. (2006).

T. cinnabarinus was obtained from cotton leaves at Huazhong Agricultural University and cultured on detached cotton leaves in an insectary at $26 \pm 2^{\circ} \mathrm{C}, 75 \pm 5 \%$ relative humidity (RH) and a 14L : 10D photoperiod. The mite was identified based on the description of Zhang \& Jacobson (2000). All spider mites used as prey in this study were in the third to fourth stadia.

\section{Experimental protocols}

The mean temperatures per month in the central region of the Yangtze River $\left(109^{\circ} 01^{\prime}-121^{\circ} 07^{\prime} \mathrm{E}\right.$ and $\left.29^{\circ} 05^{\prime}-31^{\circ} 21^{\prime} \mathrm{N}\right)$ from May to September (1990-2005) is 23.2, 25.7, 30.5, 28.4 and $24.5^{\circ} \mathrm{C}$, respectively (http://cdc.cma.gov.cn, Meteorological Data Sharing Service System of P.R. China). Thus, three temperatures $\left(25,28\right.$ and $\left.31^{\circ} \mathrm{C}\right)$ were used in this study. All experiments were conducted at a $75 \pm 5 \% \mathrm{RH}$ and a $14 \mathrm{~L}: 10 \mathrm{D}$ photoperiod in climate controlled cabinets (HP250GS, Ruihua Instrument \& Equipment Co., Ltd., Wuhan, P.R. China) equipped with fluorescent lighting controlled by an automatic timer. The variation in temperature was less than $1{ }^{\circ} \mathrm{C}$ and the light intensity was approximately $20.0 \mathrm{~W} \cdot \mathrm{m}^{-2}$.

\section{Functional response of $O$. similis to $T$. cinnabarinus}

The functional response of adult $O$. similis to different population densities of $T$. cinnabarinus was measured in Petri dishes ( $9 \mathrm{~cm}$ in diameter and $2 \mathrm{~cm}$ in depth) lined with filter paper. A single detached cotton leaf $\left(\sim 50 \mathrm{~cm}^{2}\right)$ was placed in each Petri dish as food for the mites and the petiole of the leaf was wrapped in moistened tissue, which also served as a source of water for $O$. similis. Individual mites were assigned to one of six prey densities $(6,12,18,24,36$ and 48 per dish) at each temperature. The predators were starved for $24 \mathrm{~h}$ before each assay and were 4 to 7 days old.

After $24 \mathrm{~h}$, the predators were removed and the number of dead prey counted. We assumed all dead spider mites were killed by the predator as a preliminary study indicated a nearly $100 \%$ survival of mites in the absence of predators and $100 \%$ survival of $O$. similis in the absence of mites. If the predator escaped or died, the data was discarded. Dead mites were not replaced. There were ten replicates of each prey density. All Orius bugs used in this experiment were adult females.

The mean number of prey killed as a function of prey density was plotted and the data fitted using the random predator equation of Rogers (1972):

\section{$N a=N_{0}\left\{1-\exp \left[-a T /\left(1+a T_{h} N_{0}\right)\right]\right\}$}

where $N a$ is the number of prey killed, $N_{0}$ is the initial prey density, $T$ is the total time available for attacking $(24 \mathrm{~h}), a$ is the attack rate $\left(\mathrm{h}^{-1}\right)$, and $T_{h}$ is the handling time (h) (Rogers, 1972). The parameters $a$ and $T_{h}$ were calculated using the PROC NLIN procedure in SAS (SAS Institute, 1996). A chi-square test for goodness of fit was used to compare the actual with the theoretical data.

\section{Nymphal life history study}

The survival and developmental traits of $O$. similis nymphs fed on different numbers of spider mites were measured based on the results of this predator's functional responses at three different temperatures $\left(25,28\right.$ and $\left.31^{\circ} \mathrm{C}\right)$. The results indicated that $O$. similis consumed a maximum of 24,31 and 30 spider mites in $24 \mathrm{~h}$ at 25,28 and $31^{\circ} \mathrm{C}$, respectively, when the prey density was 48 . Thus, 30 spider mites were provided per day at each temperature in all the treatments.

Approximately 500 randomly sampled fresh eggs $(<12 \mathrm{~h})$ were obtained from the insectary and incubated in a Petri dish ( $9 \mathrm{~cm}$ in diameter and $2 \mathrm{~cm}$ in depth) lined with wet filter paper. Each newly hatched nymph was coded and placed and kept in a transparent plastic tube $(15 \mathrm{~mm}$ in diameter and $75 \mathrm{~mm}$ in length) until it reached the adult stage. Each tube contained a piece of cotton leaf and 30 spider mites and was covered with water saturated cotton. The nymphs were checked twice a day (08:00 and 20:00) and transferred to new tubes daily (08:00). Thirty nymphs were used at 25,28 and $31^{\circ} \mathrm{C}$, respectively. The experiment was replicated three times. The duration of each immature stage was measured. Gender was determined immediately the adults emerged. The results for individuals that were accidentally killed were not included in the analysis.

\section{Adult life history study}

Virgin females and males were paired for mating. The pairs were observed to ensure that mating occurred and the females that remained in copulation for $>1.5$ min were assumed to have been mated (Butler \& O'Neil, 2006). The females were individually transferred to new cylindrical vitreous vials $(2.5 \mathrm{~cm}$ in diameter and $14 \mathrm{~cm}$ in length) covered with a fine mesh nylon screen. A small tender stem of Vitex negundo L. was provided as a substrate for the female $O$. similis to oviposit on following the method of Zhou et al. (2006). The end of each stem was wrapped with moistened tissue. Spider mites $(n=50)$ were brushed into the vials to provide food for the females. The stems were examined daily under a stereomicroscope $(15 \times)$ to check and count the number of eggs. Dead spider mites were replaced daily and the stems changed every four hours during the preoviposition period. After the first egg was laid the stems were changed once a day (08:00) and watered twice a day (08:00 and 20:00) to provide moisture and water for the females. Preoviposition period, oviposition period (time that elapsed between the first and last egg being laid), fecundity (total number of eggs laid over a female's lifetime) and longevity (time from adult eclosion to death) at the three temperatures were recorded. All bugs were kept and observed until they died.

\section{Life tables}

The important life table parameters, age-specific survivorship $\left(1_{\mathrm{x}}\right)$ and fecundity $\left(\mathrm{m}_{\mathrm{x}}\right)$ schedule, were calculated for $O$. similis at each temperature. Based on previous laboratory experience and the data from previous studies on other Orius spp. (Chyzik et al., 1995; Cocuzza et al., 1997), we assumed a sex ratio of 1:1 in all treatments. For each temperature, daily age-specific survival and age-specific fecundity were used to calculate the intrinsic rate of natural increase $\left(r_{m}\right)$, which is expressed as the 


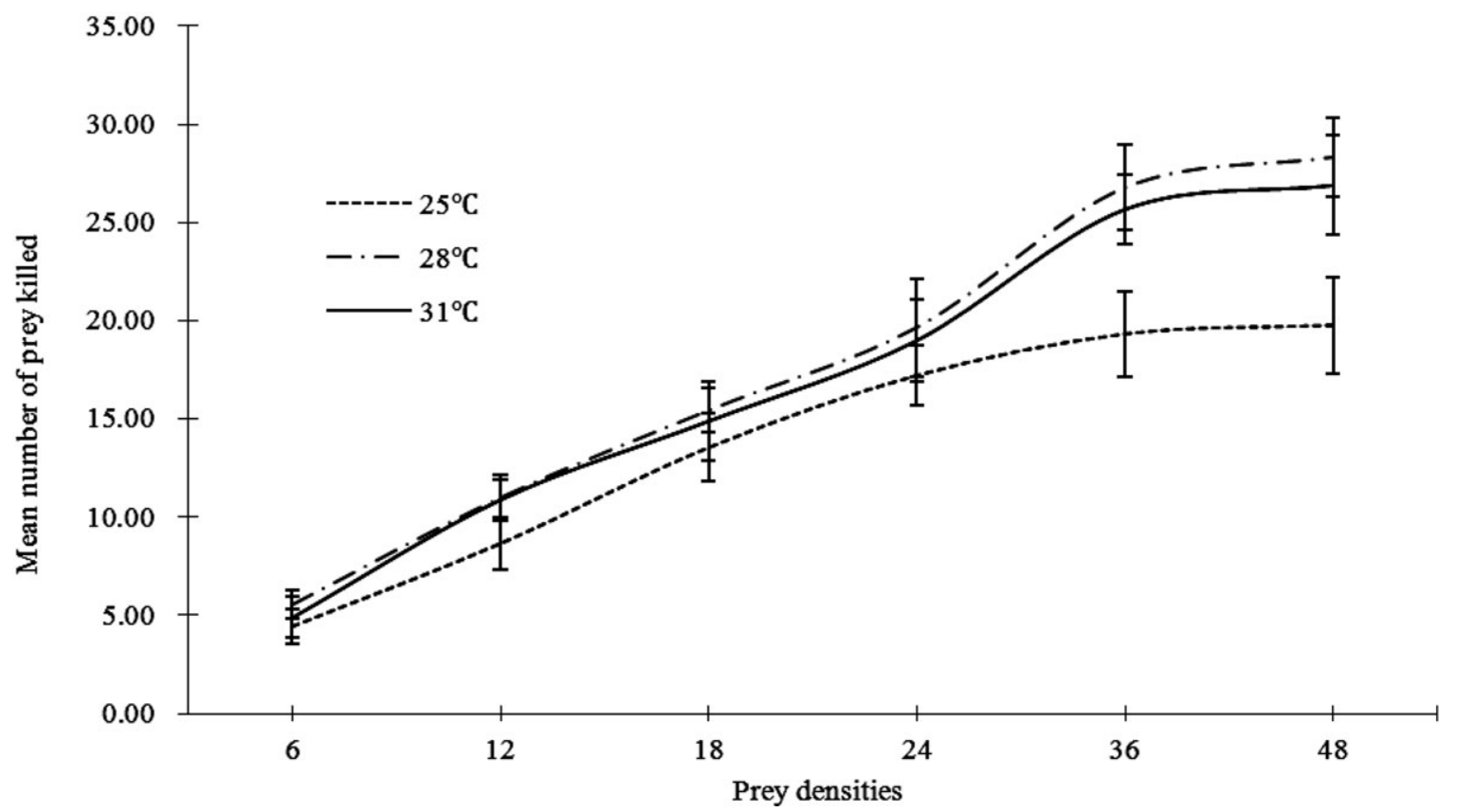

Fig. 1. Functional response of $O$. similis to the density of $T$. cinnabarinus in a Petri-dish arena recorded at three temperatures, $75 \pm$ 5\% RH and a 14L : 10D photoperiod and measured over a over a period of $24 \mathrm{~h}$. Points show average number of spider mites killed by $O$. similis at each prey density. Error bars show standard error. Each point is the average of 10 replicates.

number of females per female per day using the following formula of Birch (1948):

$$
\sum_{x-1}^{\infty} e^{-r_{m} x} l_{x} m_{x}=1
$$

where $\omega$ is the oldest age class, and $l_{x}$ and $m_{x}$ are the proportion of surviving females at age $x$ and the number of females produced per female in the age interval $x$, respectively. With a stable age distribution and under given climatic and food conditions, the intrinsic rate of natural increase is useful for comparing population growth potentials (Southwood, 1978).

In addition, net reproductive rate $\left(R_{0}\right.$ or the number of female offspring produced per female), mean generation time $(T)$ and intrinsic rate of increase $\left(r_{m}\right)$ were calculated as follows:

$$
\begin{aligned}
& R_{0}=\sum l_{x} m_{x} \\
& T=\sum l_{x} m_{x} X / \sum l_{x} m_{x} \\
& r_{m}=l_{n} R_{0} / T
\end{aligned}
$$

where $X$ is the age interval, $l_{x}$ is the survival of the immature and adult stages of the females at age $X$, and $m_{x}$ is the number of female progeny produced per female in the age interval $X$.

\section{Statistical analysis}

Data were tested for significance using the one-way analysis of variance in SPSS for Windows version 11.5 (SPSS Inc., Chicago, Illinois). The mean values were compared using Tukey's test with $\mathrm{P}=0.05$. The cumulative survival data for the nymphs were subjected to arcsine square root transformation before analysis.

\section{RESULTS}

\section{Functional response of $\boldsymbol{O}$. similis to $T$. cinnabarinus}

The number of prey killed by $O$. similis generally increased as the prey density increased. However, at a prey density of 36 spider mites per dish the curve leveled off at all the three temperatures (Fig. 1). At 28 and $31^{\circ} \mathrm{C}$, there were no significant differences between the average numbers of spider mites killed by $O$. similis at each prey density (Fig. 1). As shown in Table 1, the attack rate (a) of $O$. similis was highest at $28^{\circ} \mathrm{C}(1.04)$. The number of prey killed by $O$. similis was closely correlated with the density of prey, and the $\chi^{2}$ values $(1.1247,0.2917$, and $0.5342)$ were far less than $\chi_{0.01,5}^{2}(15.09)$.

\section{Survival and duration of development of nymphs}

The greatest cumulative survival of the nymphs $(75.57 \%)$ was recorded at $28^{\circ} \mathrm{C}$ (Table 2) and the percentage survival at 28 and $31^{\circ} \mathrm{C}(75.57 \%$ vs. $64.43 \%)$ did not differ significantly (d.f. $=2,8, \mathrm{~F}=5.027, \mathrm{P}=0.052$ ). Survival was above $50 \%$ at all three temperatures.

The analysis of the variance in the average durations of the immature stages of $O$. similis at 25,28 and $31^{\circ} \mathrm{C}$ is recorded in Table 2. The average duration of development of both females and males were significantly affected by temperature (d.f. $=2,96, \mathrm{~F}=66.725, \mathrm{P}<$ 0.001 and d.f. $=2,96, \mathrm{~F}=37.874, \mathrm{P}<0.001$ respectively). That is, it decreased with increase in temperature, with the duration of development decreasing from 23.8 to $15.6 \mathrm{~d}$ for females and from $21.2 \mathrm{~d}$ to $14.8 \mathrm{~d}$ for males when the temperature increased from 25 to $31^{\circ} \mathrm{C}$.

TABLE 1. Effect of temperature on the handling time $\left(\mathrm{T}_{\mathrm{h}}\right)$ and attack rate (a) of $O$. similis attacking $T$. cinnabarinus at $75 \pm 5 \%$ $\mathrm{RH}$ and a $14 \mathrm{~L}: 10 \mathrm{D}$ photoperiod.

\begin{tabular}{cccc}
\hline Temp. $\left({ }^{\circ} \mathrm{C}\right)$ & $\mathrm{T}_{\mathrm{h}}(\mathrm{h})$ & $\mathrm{a}\left(\mathrm{h}^{-1}\right)$ & $\chi^{2}$ \\
\hline 25 & 0.0159 & 0.8676 & 1.1247 \\
28 & 0.0130 & 1.0400 & 0.2917 \\
31 & 0.0115 & 0.9569 & 0.5342 \\
\hline
\end{tabular}

Notes: $\chi^{2}$ values were the results of chi-square test with $\mathrm{P}<$ 0.05 . 
TABLE 2. Developmental parameters of nymphs of $O$. similis fed daily on $T$. cinnabarinus at three constant temperatures, $75 \pm 5 \%$ RH and a 14L : 10D photoperiod.

\begin{tabular}{cccc}
\hline \multirow{2}{*}{ Temp. $\left({ }^{\circ} \mathrm{C}\right)$} & Average cumulative survival (\%) & female & male \\
\hline 25 & $57.80 \pm 5.88(3) \mathrm{b}$ & $23.8 \pm 0.61(33) \mathrm{a}$ & $21.2 \pm 0.61(27) \mathrm{a}$ \\
28 & $75.57 \pm 1.13(3) \mathrm{a}$ & $18.3 \pm 0.39(34) \mathrm{b}$ & $18.2 \pm 0.44(37) \mathrm{b}$ \\
31 & $64.43 \pm 4.03(3) \mathrm{ab}$ & $15.6 \pm 0.50(30) \mathrm{c}$ & $14.8 \pm 0.48(33) \mathrm{c}$ \\
Results of ANOVA & d.f. $=2,8, \mathrm{~F}=5.027, \mathrm{P}>0.05$ & d.f. $=2,96, \mathrm{~F}=66.725, \mathrm{P}<0.001$ & d.f. $=2,96, \mathrm{~F}=37.874, \mathrm{P}<0.001$ \\
\hline
\end{tabular}

Notes: Figures in parentheses indicate the number sampled. Values (means \pm SE) followed by different letters within a column are significantly different based on Tukey's test with $\mathrm{P}<0.05$.

TABLE 3. Average pre-oviposition period, reproductive period, longevity and total fecundity of $O$. similis adults fed daily on $T$. cinnabarinus at three constant temperatures, $75 \pm 5 \% \mathrm{RH}$ and a $14 \mathrm{~L}: 10 \mathrm{D}$ photoperiod.

\begin{tabular}{|c|c|c|c|c|c|}
\hline \multirow{2}{*}{ Temp. $\left({ }^{\circ} \mathrm{C}\right)$} & \multirow{2}{*}{$\begin{array}{l}\text { Pre-oviposition period } \\
\text { (days) }\end{array}$} & \multirow{2}{*}{$\begin{array}{l}\text { Oviposition period } \\
\text { (days) }\end{array}$} & \multicolumn{2}{|c|}{ Adult longevity(days) } & \multirow{2}{*}{$\begin{array}{l}\text { Total fecundity } \\
\text { (eggs) }\end{array}$} \\
\hline & & & female & male & \\
\hline 25 & $6.2 \pm 0.24(18) \mathrm{a}$ & $15.5 \pm 0.78(13) \mathrm{b}$ & $35.9 \pm 2.37(13) \mathrm{a}$ & $33.1 \pm 1.75(15) \mathrm{a}$ & $21.2 \pm 1.00(13) b$ \\
\hline 28 & $5.8 \pm 0.21(19) \mathrm{a}$ & $21.1 \pm 0.64(16) \mathrm{a}$ & $30.6 \pm 1.42(16) a b$ & $29.5 \pm 1.40(16) \mathrm{ab}$ & $40.3 \pm 2.05(16) \mathrm{a}$ \\
\hline 31 & $5.5 \pm 0.20(22) \mathrm{a}$ & $18.8 \pm 0.79(16) \mathrm{a}$ & $27.6 \pm 1.31(16) \mathrm{b}$ & $26.9 \pm 0.91(15) b$ & $34.3 \pm 1.85(16) \mathrm{a}$ \\
\hline $\begin{array}{l}\text { Results of } \\
\text { ANOVA }\end{array}$ & $\begin{array}{c}\text { d.f. }=2,58, F=2.240 \\
P>0.05\end{array}$ & $\begin{array}{c}\text { d.f. }=2,44, F= \\
13.448, P<0.001\end{array}$ & $\begin{array}{c}\text { d.f. }=2,44, F=5.935, \\
P<0.05\end{array}$ & $\begin{array}{c}\text { d.f. }=2,45, F=4.852, \\
P<0.05\end{array}$ & $\begin{array}{c}\text { d.f. }=2,44, F=28.281, \\
P<0.001\end{array}$ \\
\hline
\end{tabular}

Notes: Figures in parentheses indicate the number sampled. Values (means \pm SE) followed by different letters within a column are significantly different based on Tukey's test with $\mathrm{P}<0.05$.

\section{Longevity and fecundity of adults}

There were no significant differences in the preoviposition period recorded at the three temperatures (d.f. $=2,58, F=2.240, P=0.116$, Table 3). However, the oviposition periods did differ significantly (d.f. $=2,44$, $F=13.448, \mathrm{P}<0.001$, Table 3 ). At $25^{\circ} \mathrm{C}$, it was significantly shorter $(15.5 \mathrm{~d})$ than that of those fed on $T$. cinnabarinus at $28^{\circ} \mathrm{C}(21.1 \mathrm{~d})$ and $31^{\circ} \mathrm{C}(18.8 \mathrm{~d})$. The longevities of adults of both female and male $O$. similis declined with increase in temperature $(35.9 \mathrm{~d}$ to $27.6 \mathrm{~d}$ for females and $33.1 \mathrm{~d}$ to $26.9 \mathrm{~d}$ for males). However, there were no significant differences in the fecundity recorded at 28 and $31^{\circ} \mathrm{C}$ (female: d.f. $=2,44, \mathrm{~F}=5.935, \mathrm{P}=0.005$; male: d.f. $=2,45, \mathrm{~F}=4.852, \mathrm{P}=0.013$, Table 3$)$. The greatest fecundity was recorded at $28^{\circ} \mathrm{C}(40.3$ eggs).

\section{Life table parameters of adults}

Life table parameters of $O$. similis fed on $T$. cinnabarinus at the three temperatures are presented in Table 4. The value of net reproductive rate $\left(\mathrm{R}_{0}\right)$ increased from 13.50 at $25^{\circ} \mathrm{C}$ to 25.76 at $28^{\circ} \mathrm{C}$ and then decreased to 22.12 at $31^{\circ} \mathrm{C}$. Mean generation time $(\mathrm{T})$ declined from

TABLE 4. Life table parameters of mated $O$. similis females fed daily on $T$. cinnabarinus at three constant temperatures, 75 $\pm 5 \% \mathrm{RH}$ and a $14 \mathrm{~L}: 10 \mathrm{D}$ photoperiod. $* \mathrm{R}_{0}, \mathrm{~T}, \mathrm{r}_{\mathrm{m}}$ are the net reproductive rate, mean generation time in days and intrinsic rate of increase $\left(\right.$ day $\left.^{-1}\right)$, respectively.

\begin{tabular}{cccc}
\hline Temp. $\left({ }^{\circ} \mathrm{C}\right)$ & $\mathrm{R}_{0}$-value* & T-value* & $\mathrm{r}_{\mathrm{m} \text {-value* }}$ \\
\hline 25 & 13.50 & 30.32 & 0.086 \\
28 & 25.76 & 30.12 & 0.108 \\
31 & 22.12 & 25.87 & 0.120 \\
\hline
\end{tabular}

$30.32 \mathrm{~d}$ to $25.87 \mathrm{~d}$ with increase in temperature from $25^{\circ} \mathrm{C}$ to $31^{\circ} \mathrm{C}$. This finding is in accordance with the result that the duration of immature stage was shortest at $31^{\circ} \mathrm{C}(15.6 \mathrm{~d}$ and $14.8 \mathrm{~d}$ for females and males, respectively) (Table 2). The intrinsic rate of increase $\left(r_{m}\right)$ increased from 0.086 day $^{-1}$ to 0.120 day $^{-1}$ with increase in temperature from $25^{\circ} \mathrm{C}$ to $31^{\circ} \mathrm{C}$ (Table 4).

\section{DISCUSSION AND CONCLUSIONS}

The number of $T$. cinnabarinus eaten by $O$. similis was affected by both temperature and prey density. The consumption of $O$. similis reached a plateau at a prey density of 48 spider mites at all three temperatures (Fig. 1), indicating that at this prey density the predator is satiated, which could serve as a reference when deciding the number and when to release them in the field. The low $\chi^{2}$ values indicate that the number eaten is in accordance with the theoretical prediction for all three temperatures.

The regional climate in the area of the Yangtze River is subtropical. The Orius spp. in this area are likely to be well adapted to high temperatures, based on the results of a study on $O$. albidipennis (Cocuzza et al., 1997). The high cumulative survival $(64.43 \%)$ recorded at $31^{\circ} \mathrm{C}$ indicates that $O$. similis is able to thrive at relatively high temperatures, although its survival at this temperature was lower than at $28^{\circ} \mathrm{C}(75.57 \%)$. Together with the short duration of the immature stages, around $18 \mathrm{~d}$ at $28^{\circ} \mathrm{C}$ and $15 \mathrm{~d}$ at $31^{\circ} \mathrm{C}$, this indicates $O$. similis could be used for controlling $T$. cinnabarinus, which flourishes at temperatures above $25^{\circ} \mathrm{C}$ during the months of June, July and August in the area of the Yangtze River (Lei, 1997).

Adult females of $O$. similis need 5-6 days to complete the development of their reproductive system after 
mating, which is shorter than that recorded for $O$. insidious feeding on aphids (8-10d) and the oviposition period is also relatively shorter (average 20 vs 30) (Butler $\&$ O'Neil, 2007). The longevity of adult $O$. similis fed on $T$. cinnabarinus decreased with increasing temperature from $25^{\circ} \mathrm{C}$ to $31^{\circ} \mathrm{C}$. This result is in accordance with that recorded for $O$. albidipennis adults fed on the western flower thrips, Frankliniella occidentalis Pergande (Cocuzza et al., 1997). In addition, the longevity of $O$. similis fed on $T$. cinnabarinus at each temperature was three to five times longer than that of $O$. similis fed on Aphis gossypii Glover (Zhou et al., 2006). Butler \& O'Neil (2007) conclude that aphids are a poorer prey for $O$. insidious than other prey items, such as soybean thrips, because aphids were less often attacked by this bug when other types of prey were present. Our field observations reveal that $O$. similis has similar predatory tendency to $O$. insidiosus (S. Zhang, pers. observ.), which suggests that $O$. similis might be more effective in controlling spider mites than cotton aphids.

Egg production of $O$. similis fed on $T$. cinnabarinus (maximum of 40 eggs per female) was lower than that of Orius albidipennis fed on the thrips, $F$. occidentalis (with a range of 47-71 eggs per female) (Cocuzza et al., 1997) and on the spider mite $T$. urticae (approximately 100 eggs per female at most) at $25^{\circ} \mathrm{C}$ (Chyzik et al., 1995). It is unknown whether subtropical species of Orius are more likely to prey on thrips or T. urticae than T. cinnabarinus. However, fecundity and cumulative survival of nymphs was highest, oviposition period longest and the value of net reproductive rate $\left(\mathrm{R}_{0}\right)$ greatest for $O$. similis at $28^{\circ} \mathrm{C}$, which indicates that this species is potentially capable of maintaining a higher population at $28^{\circ} \mathrm{C}$. The average temperature in August $\left(28.4^{\circ} \mathrm{C}\right)$ in Yangtze River region is close to $28^{\circ} \mathrm{C}$ and in August the damage caused by T.cinnabarinus is the most serious (Lei, 1997). But it is uncertain whether this bug could maintain a greater population density and control spider mites in the field in August because unlike in the laboratory the temperatures in the field are very variable fluctuating from day to night and day to day. Moreover, the predatory activity of $O$. similis in fields can be affected by other factors, such as the presence of competitors, other prey items, variation in climate and human activity.

T. cinnabarinus females can develop to sexual maturity in $9 \mathrm{~d}$, and mated females can lay an average of eight eggs per female per day (approximately 60 eggs over a seven-day oviposition period) (Kazak et al., 2003). These findings indicate that the rate of population increase of $O$. similis is less than that of spider mites. Moreover, as an omnivore, O. similis is probably unlikely to prey on a single item, as in the present study. Furthermore, the predatory activity of $O$. similis can be significantly affected by competition with ladybird beetles, predatory mites and lacewings. In addition, $O$. similis is also killed and eaten in the field by bigger and more dominant predators, such as Geocoris, Nabis, Zelus, Chrysoperla and spiders (Rosenheim, 2001). The result of the survey conducted by Ge \& Ding (1996) in fields of cotton plants show that only $11.61 \%$ of pests killed by natural enemies are killed by anthocorid bugs. Therefore, attempts to control $T$. cinnabarinus in fields of cotton plants using only $O$. similis may not be effective. It is now important to determine the ratio of $O$. similis to $T$. cinnabarinus that is needed to bring about a reduction in the abundance of the mite. The results of this study provide useful information on the biology and when best to release $O$. similis in order to control the abundance of $T$. cinnabarinus in cotton fields.

ACKNOWLEDGEMENTS. We thank Jianjiang Ke, Chong Lu and Yue Pan for their assistance with the experiments. The research was supported by the 11th Five-Yearly Plan of National Key Technology R\&D Program (No. 2006BAD08A 02), the Flat Construction of State Basic Science \& Technology No. 2005DKA21105 and the National Natural Science Foundation (NSFC) (No. 30800737).

\section{REFERENCES}

Ahmadi K., Sengonca C. \& Blaeser P. 2007: Effect of two different temperatures on the biology of predatory flower bug Orius similis Zheng (Heteroptera: Anthocoridae) with two different aphid species as prey. Turk. Entomol. Derg. 31: 253-268.

BIRCH L.C. 1948: The intrinsic rate of natural increase of an insect population. J. Anim. Ecol. 17: 15-26.

Bonte M. \& De Clerce P. 2011: Influence of predator density, diet and living substrate on developmental fitness of Orius laevigatus. J. Appl. Entomol. 135: 343-350.

Butler C.D \& O'Neil R.J. 2006: Defensive response of the soybean aphid (Homoptera: Aphididae) to predation by insidious flower bug (Hemiptera: Anthocoridae). Ann. Entomol. Soc. Am. 99: 317-320.

ButLer C.D. \& O'Neil R.J. 2007: Life history characteristics of Orius insidiosus (Say) fed Aphis glycines Matsumura. Biol. Control. 40: 333-338.

Capinera J.L. 2001: Handbook of Vegetable Pests. Academica Press, California, 729 pp.

Chyzik R., Klein M. \& Bendov Y. 1995: Reproduction and survival of the predatory bug Orius albidipennis on various arthropod prey. Entomol. Exp. Appl. 75: 27-31.

Cocuzza G.E., Clerce P.D., De Veire M.V., Cock A.D., Degheele D. \& Vacante V. 1997: Reproduction of Orius laevigatus and Orius albidipennis on pollen and Ephestia kuehniella eggs. Entomol. Exp. Appl. 82: 101-104.

Dogramaci M., Arthurs S.P., Chen J., McKenzie C., Irrizary F. \& Osborneo L. 2011: Management of chilli thrips Scirtothrips dorsalis (Thysanoptera: Thripidae) on peppers by Amblyseius swirskii (Acari: Phytoseiidae) and Orius insidiosus (Hemiptera: Anthocoridae). Biol. Control 59: 340-347.

Falcon L.A. \& Smith R.F. 1973: Guidelines for Integrated Control of Cotton Insect Pests. FAO, Rome, 92 pp.

FAtHI S. 2009: The abundance of Orius niger (Wolf.) and O. minutus (L.) in potato fields and their life table parameters when fed on two prey species. J. Pest Sci. 82: 267-272.

Feng Y., Yan J., Sun W., Zhao S., Lu W., Li M. \& He L. 2011: Transcription and induction profiles of two esterase genes in susceptible and acaricide-resistant Tetranychus cinnabarinus. Pestic. Biochem. Physiol. 100: 70-73.

GE F. \& DinG Y.Q. 1996: The population energy dynamics of predacious natural enemies and their pest control. Acta Entomol. Sin. 39: 266-273. 
Guo F.Y. \& Zhaо Z.M. 1999: Study on development tendency of pesticides resistance in Tetranychus cinnabarinus (Acori: Tetranychidae). Acta Entomol. Sin. 8: 118-121.

He L., Zhao Z.M., Cao X.F., Deng X.P. \& Wang J.J. 2005: Effect of temperature on development and fecundity of resistant Tetranychus cinnabarinus (Boisduval). Acta Entomol. Sin. 48: 203-207.

Kazak C., Karut K., Kibritci C., Sekeroglu E. 2003: Evaluating the effects of five strawberry cultivars on the biology of Tetranychus cinnabarinus Boisduval (Acari: Tetranychidae) using detached leaves in greenhouse conditions. IOBC/WPRS Bull. 26: 73-77.

LeI C.L. 1997: Biological Suppression of Pink Bollworm, Pectinophora gossypiella Saunders (Lepidoptera: Gelechiidae). Science Press, Beijing, pp. 50-83.

Mo T.L. \& Liu T.X. 2006: Biology, life table and predation of Feltiella acarisuga (Diptera: Cecidomyiidae) feeding on Tetranychus cinnabarinus eggs (Acari: Tetranychidae). Biol. Control 39: 418-426.

ROGERS D. 1972: Random search and insect population models. J. Anim. Ecol. 41: 369-383.

RosenHEIM J.A. 2001: Source-sink dynamics for a generalist insect predator in a habitat with strong higher-order predation. Ecol. Monogr. 71: 93-116.

SAS INC. 1996: Changes and Enhancements through Release 6.12. SAS Institute Inc. Cary, NC, USA, 1162 pp.

Sengonca C. 1982: The principal cotton pests and their economic thresholds in the Kilikien Plain in Southern Turkey. BioControl 27: 51-56.
Southwood T.R.E. 1978: Ecological Methods with Particular Reference to the Study of Insect Populations. Chapman \& Hall, London, $524 \mathrm{pp}$.

SPSS INC. 2002: SPSS 12.0 for Windows Use Manual (version 12.0).

Xu X., Borgemeister C. \& Poehling H.M. 2006: Interactions in the biological control of western flower thrips Frankliniella occidentalis (Pergande) and two-spotted spider mite Tetranychus urticae Koch by the predatory bug Orius insidiosus Say on beans. Biol. Control 36: 57-64.

Zhang Z.Q. \& JACOBSON R.J. 2000: Using adult female morphological characters for differentiating Tetranychus urticae complex (Acari: Tetranychidae) from greenhouse tomato crops in UK. Syst. Appl. Acarol. 5: 69-76.

ZHENG L.Y. 1982: Two new species of Orius Wolff from P.R. China (Hemiptera: Anthocoridae). Acta Entomol. Sin. 25: 191-194.

ZHou X.M. \& LeI C.L. 2002: Utilization efficiency and functional response of Orius similis Zheng (Hemiptera: Anthocoridae) to different preys. Acta Ecol. Sin. 22: 2085-2090.

Zhou X.M., Zhu F., Li H. \& Lei C.L. 2006: Effect of temperature on development of Orius similis Zheng (Hemiptera: Anthocoridae) and on its predation activity against Aphis gossypii Glover (Homoptera: Aphididae). Pan-Pacific Entomol. 82: 97-102.

Received February 13, 2012; revised and accepted June 15, 2012 